\begin{tabular}{|c|c|c|}
\hline & Int.J.Curr.Microbiol.App.Sci (2016) 5(12): 603-608 & \\
\hline & International Journal of Current Microbiology and Applied Sciences & \\
\hline & ISSN: 2319-7706 Volume 5 Number 12 (2016) pp. 603-608 & \\
\hline $\begin{array}{l}\text { EXCELLENT } \\
\text { PUBLISHERS }\end{array}$ & & 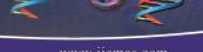 \\
\hline
\end{tabular}

Original Research Article

http://dx.doi.org/10.20546/ijcmas.2016.512.065

\title{
A Study on the Rate of vacA Genotypes of Helicobacter pylori in Gastric Biopsies obtained from Patients with Symptomatic Upper GIT Disorders
}

\author{
Balamurugan Rangasamy $^{1 *}$, Saleem Mohammed Ali ${ }^{2}$, Kaviraj Mahadevan ${ }^{1}$, \\ and R. Marudhavanan ${ }^{3}$ \\ ${ }^{1}$ Central Research Laboratory, Sri Manakula Vinayagar Medical College and \\ Hospital, Puducherry, India \\ ${ }^{2}$ Department of Microbiology, Sri Manakula Vinayagar Medical College and \\ Hospital, Puducherry, India \\ ${ }^{3}$ Department of Surgery, Sri Manakula Vinayagar Medical College and \\ Hospital, Puducherry, India \\ *Corresponding author
}

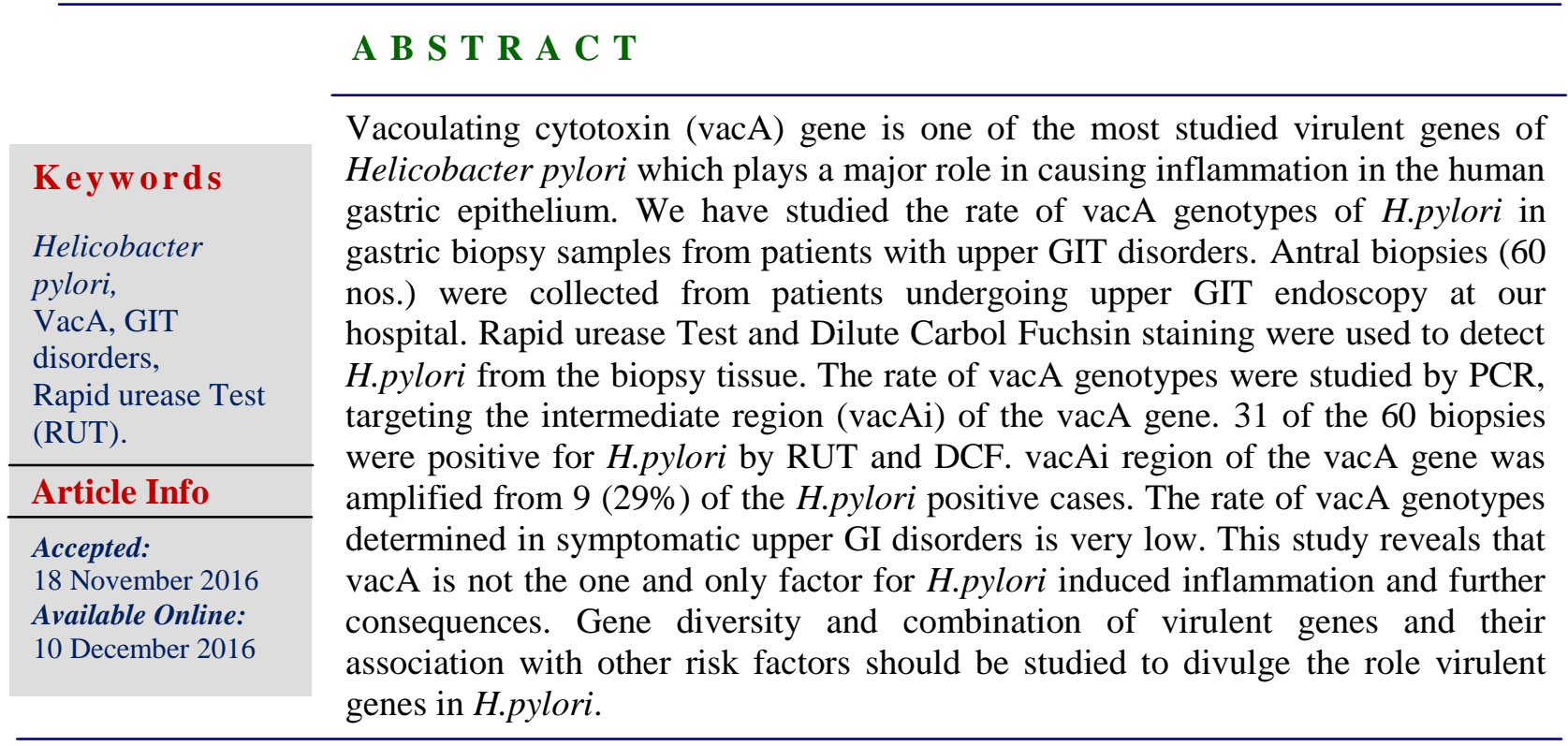

\section{Introduction}

Helicobacter pylori is the largest human pathogen which is present in more than half of the world's population. It is widely distributed in all regions of the world. H.pylori is found in the human gastric mucosa and is linked with gastritis and ulceration (Marshall et al., 1991 Francis et al., 2007). H.pylori is also found to be associated with the development of gastric carcinoma (Ashton-Key et al., 1996). H.pylori is classified as a group I carcinogen by the International Agency for Research on Cancer (IARC) (Schistosomes et al., 1994). Even when the studies evidence that H.pylori induces gastric cancer, most of the H.pylori positive people do not develop it (Martin et al., 1995). This may be due to the absence of virulent factors which determine 
the risk of developing H.pylori induced adenocarcinoma. The strains of H.pylori are more divergent, two distinct strains could co-exist in the gastric mucosa of an individual person. So the risk of developing inflammation and its further complications like gastric cancer is associated with the virulence properties of the H.pylori strain type that an individual harbors in his/her gastric mucosa (Helena et al., 2000). Bacterial virulence and their role in the pathogenesis of H.pylori has been widely studied (John, 1998). The genome of H.pylori is composed of a range of virulence genes, among which, vacuolating cytotoxin (VacA) is a well known gene of H.pylori which codes for a $95-\mathrm{kDa}$ (VacA) protein. This protein causes vacuolization of epithelial cells and plays an important role in the development of gastritis and ulcers. The Gene is composed of a Signal sequence region $(\mathrm{s} 1, \mathrm{~s} 2)$, a mid-region $(\mathrm{m} 1, \mathrm{~m} 2)$ and an intermediate-region (i1, i2, and i3). The allelic forms of signal sequence (s1, s2) and mid region $(\mathrm{m} 1, \mathrm{~m} 2)$ exist in combinations (except s2, m1) and bring about allelic diversity among the VacA gene (Anna et al., 2008; Samuel et al., 2012). The aim of the present study is to find the rate of vacA genotypes present in gastric biopsies collected from patients with upper GI disorders by PCR amplification of the VacA intermediate region ( $\mathrm{Vac} \mathrm{Ai}$ ).

\section{Materials and Methods}

\section{Study subjects}

60 patients suggested for upper GIT endoscopy after clinical examination in Sri Manakula Vinayagar Medical College and hospital puducherry were included in this study. Subjects were selected based upon the inclusion criteria; 1) a well defined clinical symptom like dyspepsia, dysphagia, abdominal pain, etc, 2) clinically diagnosed with a minimum of one GIT disorder caused by H.pylori like, gastritis, duodenitis, peptic ulcer disease, etc. subjects with all other endoscopic findings and endoscopic normal studies were excluded from the study. Samples were collected only from those who have agreed to co operate this study. Detailed consent was obtained from each patient. Among the 60 selected subjects, 32 were male and 28 were female with age starts from 17 to 63 .

\section{Sample collection}

Antral gastric biopsies were collected as +/$5 \mathrm{~mm}$ tissues in sterile normal saline. Three bits of tissues were collected from each patient for RUT (Rapid urease Test), DCF (Dilute Carbol Fuchsin) and PCR (Polymerase Chain Reaction) respectively.

\section{Rapid urease Test (RUT)}

A bit of freshly collected biopsy tissue was transferred to $1.5 \mathrm{ml}$ of Christenson urea broth and incubated at $37^{\circ} \mathrm{C}$. The samples were observed for every one hour for the development of pink color in Christenson urea broth which is considered as positive for H.pylori. Sterile Christenson urea broth without biopsy tissue served as a negative control.

\section{Dilute Carbol Fuchsin (DCF) staining}

Samples were collected and transferred to the laboratory within one hour for further processing. A smear was made by rubbing the tissue against slide and fixed with methanol for 3 minutes. The fixed smear was stained with carbol fuchsin (1:10 dilution) for 10 minutes and viewed under 100X oil immersion microscope for the presence of spiral bacilli.

\section{DNA isolation}


DNA isolation was done manually by phenol chloroform extraction method. The biopsy tissue was minced with the help of sterile scalpel and forceps. The minced tissue was incubated overnight at $56^{\circ} \mathrm{C}$ in $200 \mu \mathrm{l}$ of tissue lysis buffer (tris-HCL $100 \mathrm{~mm}+100 \mathrm{~mm}$ EDTA+ $100 \mathrm{~mm} \mathrm{NaCl}+$ $1 \% \mathrm{SDS}$ ) and $10 \mu \mathrm{l}$ of proteinase $\mathrm{K}$. Equal volume of phenol(24): chloroform(24): isoamylalcohol(01) was added to the digested tissue, mixed well and centrifuged at 10000RPM for 5 minutes. DNA was precipitated from the aqueous phase using absolute ethanol.

\section{Polymerase Chain Reaction (PCR)}

All the 60 biopsies were taken for the detection of vacA genotypes. PCR was performed using primers, VacA-1.SE CAATCGTGTGGGTTCTGGAGC, VacA3. As GCCGATATGCAAATGAGCC GC described by Monstein et.al, 2002, targeting the $678 \mathrm{bp}$ intermediate region of vacA gene. $500 \mu \mathrm{m}$ of each forward and reverse primer, $5 \mu 1$ of template DNA were used in a $50 \mu \mathrm{l}$ of $1 \mathrm{X}$ master mix (TakaraEmraldAmp). Amplification was done in BIO-RAD T100 Thermal Cycler with 35 cycles of initial denaturation at $93^{\circ} \mathrm{C}$ for 5 minutes, cycle denaturation at $93^{\circ} \mathrm{C}$ for 1 minute, annealing at $58^{\circ} \mathrm{C}$ for 1 minute, cycle extension at $72^{\circ} \mathrm{C}$ for 1 minute, final extension at $72^{\circ} \mathrm{C}$ for 5 minutes and hold at $4^{0} \mathrm{C}$ for 5 minutes. The resulting product was viewed in $1 \%$ agarose gel with 100bp DNA marker.

\section{Results and Discussion}

$31(52 \%)$ out of 60 samples were positive for H.pylori by RUT and DCF staining in which, 14 were male and 16 were female (Figure.1). 9(29\%) of the samples got amplified (678) for vacA gene, none of the RUT \& DCF negative samples gave positive result (Figure.2). Two of the 9 vacA samples were sequenced and blasted (Query ID: lcl|Query_190267 \& lcl|Query_115345) against the sequences available in the NCBI database. The sequences have shown $95 \%$ and $98 \%$ similarities against the NCBI Helicobacter pylori strain PG218 VacA (vacA) gene, complete cds; accession number: GQ331974.1 and Helicobacter pylori SNT49, complete genome; accession number: CP002983.1 respectively.

The rate of H.pylori in patients with upper GI disorders by RUT and DCF staining is $51.6 \%$ which is compatible with the studies reported from many parts of India $(12,13)$ It is important to know the genotype of H.pylori present in the patient to understand the risk of developing H.pylori induced gastritis and/or adenocarcinoma. It also reveals information about the importance of rapid eradication of H.pylori (Kidd et al., 1999; Mahsa et al., 2010).

The vacA gene is found to be closely associated with in vitro cytotoxicity and also to the clinical consequences of the patient. Studies also show that vacA positive genotypes were isolated from patients with no defined clinicopathological condition. This phenomenon can be explained by the fact that the vacA gene is highly divergent and sequence variations may contribute to the pathogenicity of the particular strain. Amplification of H.pylori DNA from direct gastric biopsies is crucial due to the presence of very less amount of bacterial DNA and also the presence of PCR inhibitors in the biopsy tissue.

The rate of vacA genotypes found in this study is $29 \%$ which is lesser than that of the other studies reported from different parts of Asia viz. palastine, bharian, india. (Tamer et al., 2013). The low level of vacA genotypes in upper GI disorders show that vacA alone is not a risk factor for developing H.pylori 
associated complications. A study on the combination of other virulent factors along with vacA is essential to know the pathogenicity of H.pylori. For example, the presence of vacAi sequence is found to be associated with cagA positivity and overall virulence of the strain (Vandenplas, 1999).

Fig.1 Prevalence of H.pylori in GIT disorders detected by Rapid Urease Test (RUT) Dilute Carbol Fuchsin (DCF) staining

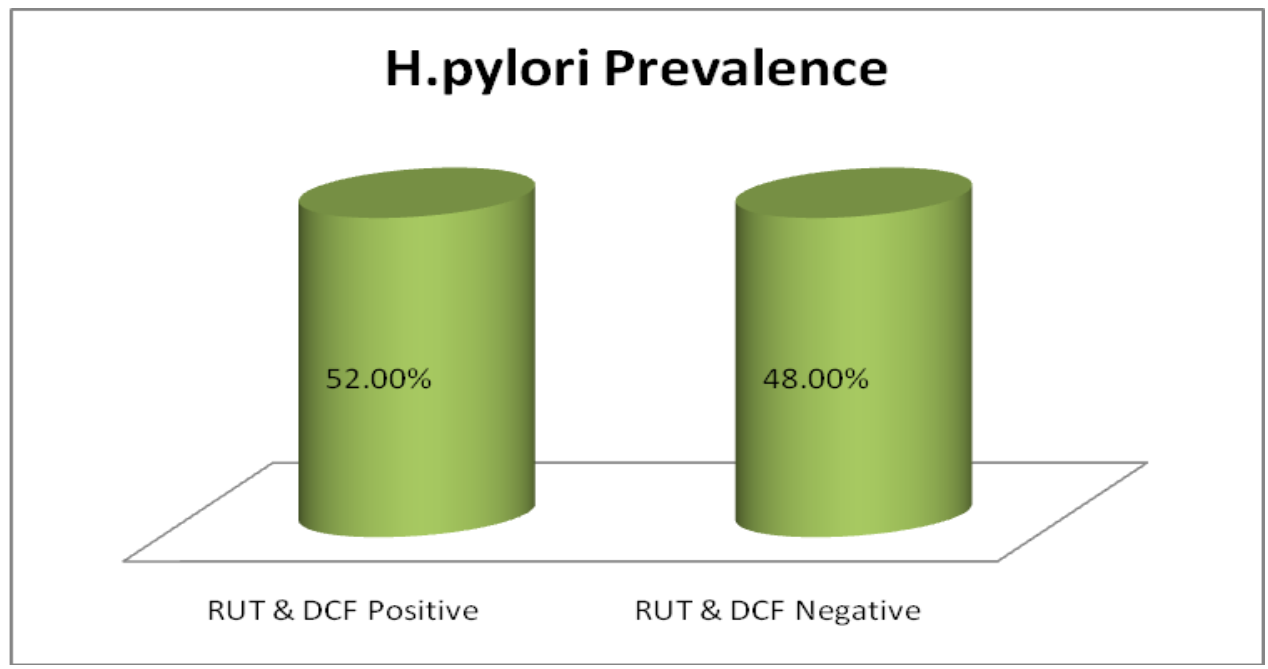

The prevalence of H.pylori among patients attending a tertiary care hospital in puducherry is found to be $52 \%$

Fig.2 Agarose gel electrophoresis showing 678bp vacAi region.

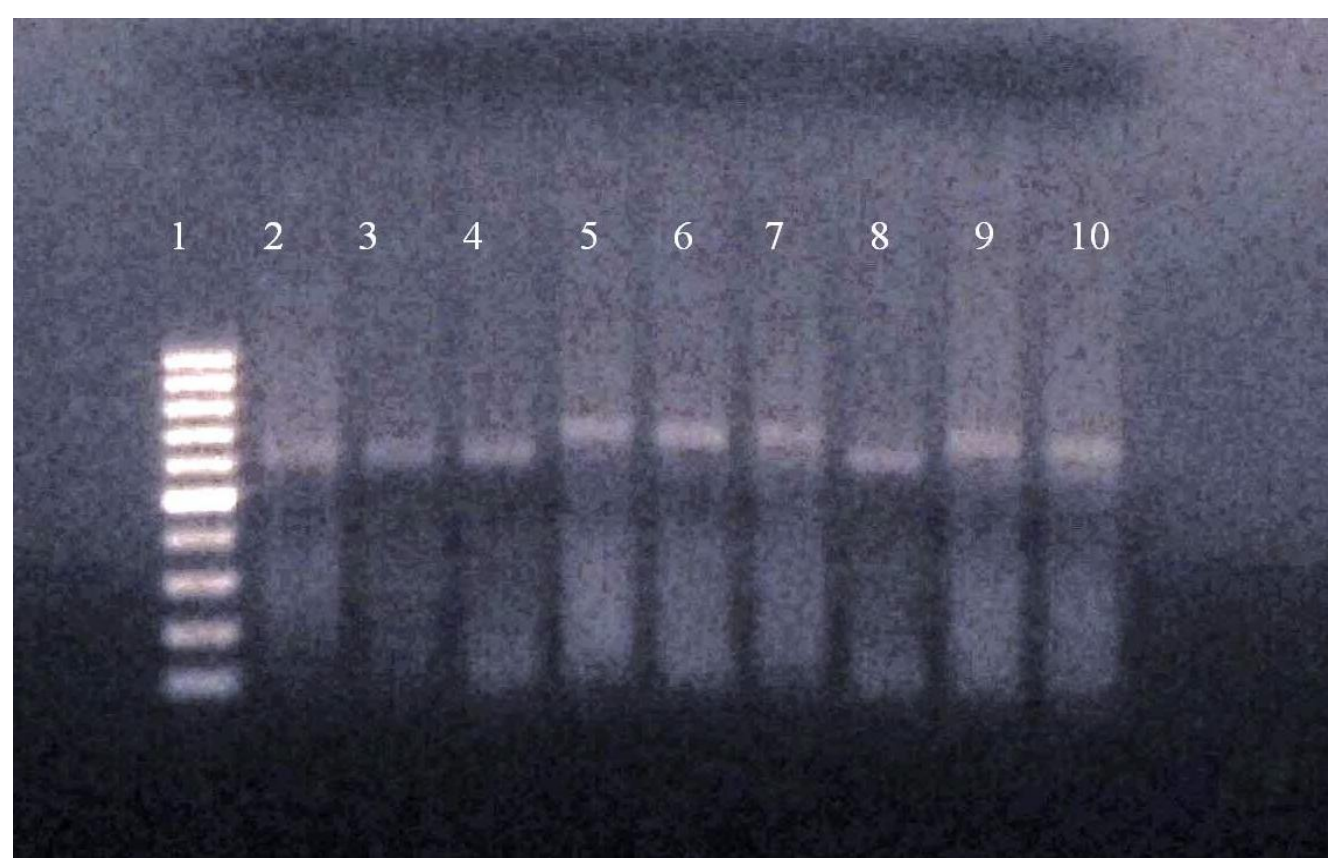

Lane 1: 100bp DNA marker, Lane 2 to $10:$ H.pylori samples showing positive result for vacAi at $678(650-700) \mathrm{bp}$. 
Presence or absence of the functional vacA gene and its association to the virulence of the strain is controversial. It is also important to analyze the complete sequence (combination of (s1, s2), (i1, i2, and i3) \& $(\mathrm{m} 1, \mathrm{~m} 2))$ of vacA gene for the presence of a functional vacA protein.

In conclusion, this study is a reference for the rate of H.pylori vacA genotypes of this area. The present study states that vacAi positivity in symptomatic upper GI disorders is low. Further studies on the full length sequence analysis of vacA gene and its coexistence with other risk factors would give useful information about its diversity and role in H.pylori pathogenesis.

\section{Acknowledgement}

We would like to thank the management of Sri Manakula Vinayagar Medical College and Hospital for providing financial and facility support for this study. We are also thankful to the technicians and staffs of the central research laboratory, department of microbiology and department of surgery, Sri Manakula Vinayagar Medical College and Hospital, for their valid contribution

\section{References}

Adlekha, S., T. Chadha, P. Krishnan, and B. Sumangala. 2013. Prevalence of helicobacter pylori infection among patients undergoing upper gastrointestinal endoscopy in a medical college hospital in kerala, India. Ann. Med. Health Sci. Res., 3(4): 559-563.

Anna Ryberg, Kurt Borch, Yi-Qian Sun and Hans-Jurg Monstein. Concurrent genotyping of Helicobacter pylori virulence genes and human cytokine SNP sites using whole genome amplified DNA derived from minute amounts of gastric biopsy specimen DNA. BMC Microbiol., 8:175: 1-15.
Ashton-Key, M., T.C. Diss, P.G. Isaacson. 1996. Detection of Helicobacter pylori in gastric biopsy and resection specimens. J. Clin. Pathol., 49(2): 107111.

Christine Chung, Asalia Olivares, Eugenia Torres, Ozlem Yilmaz, Henry Cohen, and Guillermo Perez-Perez. Diversity of VacA Intermediate Region among Helicobacter pylori Strains from Several Regions of the World. J. Clin. Microbiol., 48(3); 690-696.

Francis Me graud, Philippe Lehours. 2007. Helicobacter pylori Detection and Antimicrobial Susceptibility Testing. Clin. Microbiol. Rev., 20(2): 280-322.

Gill, H.H., Desai, H.G., Majmudar, P., Mehta, P.R., Prabhu, S.R. 1993. Epidemiology of Helicobacter pylori: the Indian scenario. Indian J. Gastroenterol., 12(1): 9-11.

Helena Enroth, Wolfgang Kraaz, Lars Engstrand, Olof Nyre'n, and Tom Rohan. 2000. Helicobacter pylori Strain Types and Risk of Gastric Cancer: A Case-Control Study. Cancer Epidemiology, Biomarkers \& Prevention, Vol. 9, 981-985.

Johannes, G., Kusters, Arnoud, H.M. van Vliet, and Ernst, J. 2006. Kuipers. Pathogenesis of Helicobacter pylori Infection. Clin. Microbiol. Rev., 19(3): 449-490.

John, C. Atherton. 1998. H. pylori virulence factors. British Med. Bull., 54(1): 105120.

Khalid Mubarak Bindayna. 2009. Ali Al Mahmeed. vacA genotypes in Helicobacter pylori strains isolated from patients with and without duodenal ulcer in Bahrain. Indian J. Gastroenterol., 28(5): 175-179.

Khawaja Shakeel Ahmed, Basheer Madompoyil, Anghesom Ambesajir Ghebremedhin, John Issac, Janak Dulari Ahi, Aleem Ahmed Khan, et al. 2013. Studying the Importance of VacA Gene of Helicobacter pylori in Identifying the Pathogenicity of Strains by Comparing 
It with the Disease Status of the Subjects. J. Cancer Ther., 4: 68-74.

Kidd, M., A.J. Lastovica, J.C. Atherton, J.A. Louw. 1999. Heterogeneity in the Helicobacter pylori vacA and cagA genes: association with gastroduodenal disease in South Africa? Gut, 45: 499502.

Mahsa Molaei, Forough Foroughi, Reza Mashayekhi, Mehrdad Haghazali, Homayoon Zojaji, Fereshteh Jafari, et al. 2010. CagA status and VacA subtypes of Helicobacter pylori in relation to histopathologic findings in Iranian population. Indian J. Pathol. Microbiol., 53(1); 24-27.

Manente, L., Perna, A., Buommino, E., Altucci, L., Lucariello, A., Citro, G., et al. 2008. The Helicobacter pylori's protein VacA has direct effects on the regulation of cell cycle and apoptosis in gastric epithelial cells. J. Cell Physiol., 214(3): 582-7.

Marshall, B.J. 1991. Virulence and pathogenicity of Helicobacter pylori. $J$. Gastroenterol. Hepatol., 6(2): 121-124.

Martin, J., Blaser, Guillermo, I., Perez-Perez, Harry Kleanthous, Timothy, L., Cover, Richard, M., Peek, P.H. Chyou, et al. 1995. Infection with helicobacter pylori strains possessing cagA is associated with an increased risk of developing adenocarcinoma of the stomach. Cancer Res., 15; 55(10): 2111-2115.
Samuel, L., Palframan, Terry Kwok and Kipros Gabriel. 2012. Vacuolating cytotoxinA (VacA), a key toxin for Helicobacter pylori pathogenesis. Front Cell Infect. Microbiol., 12; 2: 92.

Schistosomes. 1994. Liver flukes and Helicobacter pylori. IARC working group on the evaluation of carcinogenic risks to humans. IARC monographs on the evaluation of carcinogenic risks to humans, 61: 177-188.

Sugimoto, M., Y. Yamaoka. 2009. The association of vacA genotype and Helicobacter pylori-related disease in Latin American and African populations. Clin. Microbiol. Infect., 15: 835-842.

Tamer Essawi, Wail Hammoudeh, Israr Sabri, Walid Sweidan, and Mohammad, A. Farraj. 2013. Determination of Helicobacter pylori Virulence Genes in Gastric Biopsies by PCR. ISRN Gastroenterol., 3: 1-4.

Vandenplas. 1999. Helicobacter pylori infection. Clin. Microbial. Infect., 5: 111.

Yoshiyuki Ito, Takeshi Azuma, Shigeji Ito, Hiroyuki Suto, Hideki Miyaji, Yukinao Yamazaki, et al. 1998. Full-Length Sequence Analysis of the vacA Gene from Cytotoxic and Noncytotoxic Helicobacter pylori. J. Infect. Dis., 178(5): 1391-8.

\section{How to cite this article:}

Balamurugan Rangasamy, Saleem Mohammed Ali, Kaviraj Mahadevan and R. Marudhavanan. 2016. A Study on the Rate of vacA Genotypes of Helicobacter pylori in Gastric Biopsies obtained from Patients with Symptomatic Upper GIT Disorders. Int.J.Curr.Microbiol.App.Sci. 5(12): 603-608. doi: http://dx.doi.org/10.20546/ijcmas.2016.512.065 